\title{
Article \\ Match Physical and Physiological Response of Amateur Soccer Referees: A Comparison between Halves and Match Periods
}

\author{
Eñaut Ozaeta ${ }^{1} \oplus$, Uxue Fernández-Lasa ${ }^{2} \oplus$, Inmaculada Martínez-Aldama ${ }^{3}$, Ruth Cayero ${ }^{3}$ and Daniel Castillo ${ }^{4, *}(\mathbb{C}$ \\ 1 Faculty of Education and Sport, University of the Basque Country, UPV/EHU, 01007 Vitoria-Gasteiz, Spain; \\ eozaeta001@gmail.com \\ 2 Society, Sports and Physical Exercise Research Group (GIKAFIT), Physical Education and Sport Department, \\ Faculty of Physical Activity and Sports Science, University of the Basque Country, UPV/EHU, \\ 01007 Vitoria-Gasteiz, Spain; uxue.fernandez@ehu.eus \\ 3 Physical Education and Sport Department, Faculty of Education and Sport, University of the Basque Country, \\ UPV/EHU, 01007 Vitoria-Gasteiz, Spain; inmaculada.martinezdealdama@ehu.eus (I.M.-A.); \\ ruth.cayero@ehu.eus (R.C.) \\ 4 Faculty of Education, University of Valladolid, 42004 Soria, Spain \\ * Correspondence: danicasti5@gmail.com
}

check for

updates

Citation: Ozaeta, E.; Fernández-Lasa, U.; Martínez-Aldama, I.; Cayero, R.; Castillo, D. Match Physical and Physiological Response of Amateur Soccer Referees: A Comparison between Halves and Match Periods. Int. J. Environ. Res. Public Health 2022, 19, 1306. https://doi.org/10.3390/ ijerph19031306

Academic Editor: Paul B. Tchounwou

Received: 7 January 2022

Accepted: 22 January 2022

Published: 24 January 2022

Publisher's Note: MDPI stays neutral with regard to jurisdictional claims in published maps and institutional affiliations.

Copyright: (C) 2022 by the authors. Licensee MDPI, Basel, Switzerland. This article is an open access article distributed under the terms and conditions of the Creative Commons Attribution (CC BY) license (https:// creativecommons.org/licenses/by/ $4.0 /)$.

\begin{abstract}
The aim of this paper was to examine the differences in the external and internal load in amateur match officials between the 1 st and 2 nd half and among different 15 min periods. Twenty-three field referees (FRs) and 46 assistant referees (ARs) from the Spanish División de Honor participated in this study. Match external and internal loads were monitored showing that FRs recorded a lower Power $_{\text {mean }}$, Speed $_{\text {mean }}$, Cadence ${ }_{\text {mean }}$ and Stiffness mean $(p<0.05 ; \mathrm{d}=0.52$ to 0.57$)$ during the 2 nd half and they also recorded a lower $\mathrm{HR}_{\text {mean }}$, and $\mathrm{HR}_{\text {peak }}$, and spent less time in zone $5(p<0.05 ; \mathrm{d}=0.50$ to 0.62 ). The FRs' match load decreased during the match but they performed higher Power $_{\text {mean }}$ and covered more distance in the last $15 \mathrm{~min}$ of the match $(p<0.01 ; \mathrm{d}=0.87$ to 4.28$)$. The ARs external load did not show significant variations between halves, but ARs recorded a lower $\mathrm{HR}_{\text {mean }}$ and spent less time in zone $5(p<0.01 ; \mathrm{d}=0.41$ to 0.63$)$, and the highest values of Power mean, $_{\text {Speed }}$ mean,

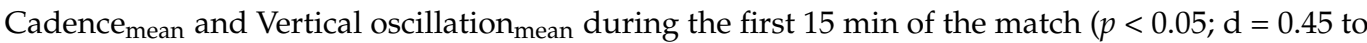
0.75). The highest values of $H_{\text {mean }}$ and distance covered were in the $0-15$ min period. Results suggest that match load decreases as the match progresses because of the neuromuscular fatigue but increases in the last $15 \mathrm{~min}$.
\end{abstract}

Keywords: field referees; assistant referees; match periods; external load; heart rate

\section{Introduction}

Field referees (FRs) and assistant referees (ARs) are responsible for controlling and supervising football matches. To be able to carry out their role, from a physical and physiological point of view, referees perform several intermittent actions throughout the match, spending time standing, walking, running at different intensities and also moving in non-orthodox modes [1,2]. Both FRs and ARs must have an adequate physical condition that allows them, on the one hand, to be correctly positioned during the match and, on the other hand, to follow the match pace, in order to make correct decisions [3]. Due to the importance of the physical and physiological dimension of refereeing, the FRs' and ARs' physical condition [4-6] and match load [7-9] have been the subject of study in recent years. With regard to match load, several studies have gone into greater depth in the analysis of external and internal match load [10-12].

Whereas the FRs cover the entire field of play, the ARs are limited to the touchline, which is why differences have been described in external and internal match loads $[13,14]$. With regard to the external load, while FRs cover a total distance of between $9 \mathrm{~km}$ and $12 \mathrm{~km}$ per match $[1,8,15]$, ARs cover a total distance of $\approx 6 \mathrm{~km}$ per match $[13,15]$, which is 
approximately $33 \%$ to $50 \%$ less than the FRs' total distance. It has also been found that the distance covered at different intensities is higher in FRs in comparison to ARs [13,14]. FRs covered more distance at high intensity $\left(>13 \mathrm{~km} \cdot \mathrm{h}^{-1}\right)$ [16] than ARs. Similarly, FRs covered $798.32 \pm 310.19 \mathrm{~m}$ at high speed $\left(>18 \mathrm{~km} \cdot \mathrm{h}^{-1}\right)$ which is $66 \%$ less than the distance covered by ARs at high speed $273.74 \pm 132.11 \mathrm{~m}$ [10]. Moreover, internal match load has also been studied demonstrating differences between FRs and ARs. For example, mean heart rate $\left(H R_{\text {mean }}\right)$ in FRs is over $85 \%$ of their maximal heart rate $\left(H R_{\max }\right)$ [17-19] while in ARs the $\mathrm{HR}_{\text {mean }}$ is $77 \%$ of their $\mathrm{HR}_{\max }$ [20]. Similarly, the $\mathrm{HR}_{\text {mean }}$ in FRs is $152.87 \pm 11.44 \mathrm{bpm}$ and in ARs is $132.73 \pm 13.63 \mathrm{bpm}$, as described by Castillo et al. [6]. Regarding match load, FRs showed higher Edwards Training Impulse (TRIMP) and Stagno's TRIMP values than ARs $[9,21]$. Current knowledge seems to show that external and internal loads are higher for FRs than ARs.

While many studies have focused on analyzing external and internal load in FRs and ARs during the entire match, fewer studies have focused on analyzing whether there are differences between the 1 st and 2 nd half $[22,23]$. It has been observed that FRs covered less distance in the 2 nd half than in the 1st half $[24,25]$ and they also performed fewer accelerations, distance covered in accelerating [23] and distance at high speed [22]. When internal load is observed, FRs $\mathrm{HR}_{\text {mean }}$ and peak heart rate $\left(\mathrm{HR}_{\text {peak }}\right)$ are lower in the $2 \mathrm{nd}$ half compared to the 1st half [14,26]. Similarly, ARs showed less distance covered in the 2nd half compared to the 1st half [25] and less distance covered at high speed [22]. Besides analyzing the differences in the external and internal match load between the 1st and 2 nd half, some studies have investigated the evolution of the external and internal load in different shorter periods during the match (i.e., $15 \mathrm{~min}$ ) [13,15,27]. Knowing the evolution of the load in shorter periods can provide relevant information on the physical and physiological requirements at different times of the match. Previous studies in both FRs and ARs have observed that both external and internal loads, measured by different variables, appear to be higher in the initial periods of the match and that there is a decline in the load as the match progresses $[13,15,18,27]$. Similarly, it has been found that some external and internal load variables are lower in the final periods of both the 1st and 2nd half $[15,18,28]$. However, most of the published studies have been carried out with high level match officials $[13,17,28]$ and no studies have analyzed the evolution of the load at different moments of the match (i.e.,15 min periods) in amateur referees. Knowing officials' match load evolution can be especially relevant because it provides more detailed information on the distribution of the physical and physiological load, and it would be interesting to study the evolution of the load in amateur referees.

Therefore, the objectives of this study were to describe the differences in external and internal load in amateur match officials (FRs and ARs) between the 1st and 2nd half, and to analyze the differences among $15 \mathrm{~min}$ periods of the match (0-15 $\mathrm{min}, 15-30 \mathrm{~min}$, 30-45 $\mathrm{min}, 45-60 \mathrm{~min}, 60-75 \mathrm{~min}$ and $75-90 \mathrm{~min}$ ).

\section{Materials and Methods}

\subsection{Participants}

Sixty-nine Spanish match referees, who officiated soccer matches in the Spanish "Division de Honor" during the 2019-2020 competitive season, participated in the present study. Twenty-three of them were FRs (age: $25.65 \pm 3.30$ years; height: $173.4 \pm 3.81 \mathrm{~cm}$; body mass: $64.86 \pm 5.82 \mathrm{~kg}$; body mass index (BMI): $21.56 \pm 1.67 \mathrm{~kg} \cdot \mathrm{m}^{-2)}$ and 46 were ARs (age: $23.11 \pm 4.15$ years; height: $178.15 \pm 4.30 \mathrm{~cm}$; body mass: $72.84 \pm 6.67 \mathrm{~kg}$; BMI: $22.94 \pm 1.87 \mathrm{~kg} \cdot \mathrm{m}^{-2}$ ). They had officiated soccer matches at this competitive level for at least three years. All the participants trained at least twice a week and were involved in refereeing in this category on average twice per month. This investigation was performed in accordance with the Declaration of Helsinki (2013) and was approved by the Ethics Committee (CEISH) of The University of the Basque Country (UPV / EHU) (Code: M10/2018/289). 


\subsection{Procedures}

To carry out this study 23 official matches were recorded during the in-season period (i.e., from December to February). Throughout all the matches, external match load (distance, power, speed, cadence, vertical oscillation, ground contact time and stiffness) and internal match load (heart rate, HR) were recorded in both FRs' and ARs' groups. A comparative design was used to examine the differences between the 1st and 2nd half and among periods of $15 \mathrm{~min}$ both in external and internal match load. Data was collected during 23 official in-season matches (i.e., from December to February). All matches were played between 11 a.m. and 5 p.m. Before the beginning of the match all the officials performed a 10 min warm-up < consisting of running, stretching, short sprints and progressive sprints. The 15 min half-time data were excluded from the external and internal match load analysis.

\subsection{Measures}

External match loads. External loads were monitored using a Stryd Power Meter (Stryd, Inc., Boulder, CO, USA) placed on the laces of the right soccer boot with a plastic clip [29]. Stryd Power Meter was used to carry out this study because its repeatability has been demonstrated $(\mathrm{SEM} \leq 12.5 \mathrm{~W}, \mathrm{CV} \geq 4.3 \%$, ICC $\leq 0.989)$ [30]. Offline data collection was activated in accordance with the manufacturer's recommendations. The external match load data were collected as measures of total distance covered $(\mathrm{km})$, average power $\left(\right.$ Power $\left._{\text {mean }}, \mathrm{W}\right)$, average speed $\left(\right.$ Speed $\left._{\text {mean }}, \mathrm{km} \cdot \mathrm{h}^{-1}\right)$, average cadence

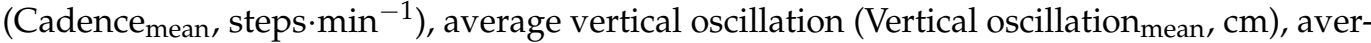
age ground contact time $\left(\mathrm{GCT}_{\text {mean }}, \mathrm{m} \cdot \mathrm{s}^{-1}\right.$ ) and average stiffness (Stiffness mean, $\mathrm{KN} \cdot \mathrm{m}^{-1}$ ).

Internal match loads. Match officials' HR was recorded during the whole match with a Polar Team 2 device (Polar Team System ${ }^{\mathrm{TM}}$, Kempele, Finland) according to the method previously used with football match officials by Castillo et al. [6]. The TRIMP based on Edwards (1993) was calculated by the sum of the values obtained multiplying the time spent in five arbitrary HR zones (from zone 1 to zone 5) by the value of each zone $[9,31]$. The zones were calculated as a percentage of peak $\mathrm{HR}\left(\mathrm{HR}_{\text {peak }}\right)$ obtained during the whole match [7]. The TRIMP value is represented in arbitrary units (AU).

\subsection{Statistical Analysis}

Results are presented as mean \pm standard deviation. Normal distribution and homogeneity of variances were tested using the Kolmogorov-Smirnov and Levene tests. Student's $t$-test for paired samples was performed in order to evaluate mean differences between the 1st and 2nd half in FRs' and ARs' external and internal match loads. Repeated measures of ANOVA and Bonferroni's post hoc were used to analyze mean differences among the periods of $15 \mathrm{~min}(0-15,15-30,30-45,45-60,60-75$ and 75-90 min) in FRs' and ARs' external and internal match loads. Practical significance was assessed by Cohen's $\mathrm{d}$ [32], with values of above 0.8 , between 0.8 and 0.5 , between 0.5 and 0.2 , and lower than 0.2 being considered large, moderate, small, and trivial, respectively. We performed all statistical power calculations via G*Power 3.1.9.2 (Universität Kiel, Kiel, Germany) and supported this sample size for comparisons between two dependent means using power $=0.80, \alpha=0.05$, and effect size $=0.50$. Considering the ANOVA test for repeated measures, the total sample size $(n=23)$, an effect size $f$ of 0.25 , an alpha error of 0.05 and a 0.5 of correlation among repeated measures, we obtained a statistical power of 90\%. The data analysis was carried out using JASP (JASP Team (2021), JASP version 0.16, Amsterdam, The Netherlands). Statistical significance was set at $p<0.05$.

\section{Results}

The differences recorded by FRs between the 1st and 2nd half in external and internal loads during the official matches are shown in Table 1 . When external loads are observed,

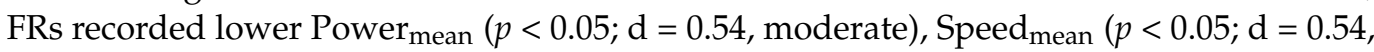
moderate), Cadence mean $(p<0.05 ; \mathrm{d}=0.52$, moderate) and Stiffness mean $(p<0.05 ; \mathrm{d}=0.57$, 
moderate) in the 2 nd half than in the 1 st half. No significant differences $(p>0.05)$ were found in distance, vertical oscillation or ground contact time between both halves. FRs spent more time in zone 2 , zone 3 and zone $4(p<0.05 ; \mathrm{d}=0.45$ to 0.69 , moderate) in the 2nd half compared to the 1 st half, and spent less time in zone $5(p<0.01 ; \mathrm{d}=0.62$, moderate) during the 2nd half. In addition, FRs recorded lower values in $\mathrm{HR}_{\text {mean }}(p<0.05 ; \mathrm{d}=0.56$, moderate) and $\mathrm{HR}_{\text {peak }}(p<0.05 ; \mathrm{d}=0.50$, small) in the 2 nd half compared to the values obtained in the 1st half.

Table 1. Differences in external and internal match loads between 1st half and 2nd half in FRs.

\begin{tabular}{|c|c|c|c|c|}
\hline & 1st Half & 2nd Half & $p<$ Value & Cohen's d \\
\hline \multicolumn{5}{|l|}{ External loads } \\
\hline Distance $(\mathrm{km})$ & $4.30 \pm 0.48$ & $4.35 \pm 0.45$ & 0.52 & -0.14 \\
\hline Power $_{\text {mean }}(\mathrm{W})$ & $122.80 \pm 11.81$ & $118.67 \pm 12.46$ & $0.02 *$ & 0.54 \\
\hline Power $_{\text {peak }}(W)$ & $402.5 \pm 54.94$ & $402.98 \pm 75.98$ & 0.97 & -0.01 \\
\hline Speed $_{\text {mean }}\left(\mathrm{km} \cdot \mathrm{h}^{-1}\right)$ & $7.22 \pm 0.63$ & $7.01 \pm 0.69$ & $0.02 *$ & 0.54 \\
\hline $\operatorname{Speed}_{\text {peak }}\left(\mathrm{km} \cdot \mathrm{h}^{-1}\right)$ & $23.32 \pm 2.06$ & $23.24 \pm 1.96$ & 0.86 & 0.04 \\
\hline Cadence $_{\text {mean }}\left(\right.$ steps $\cdot \min ^{-1}$ ) & $63.32 \pm 2.05$ & $62.33 \pm 1.95$ & $0.02 *$ & 0.52 \\
\hline Cadence $_{\text {peak }}\left(\right.$ steps $\left.\cdot \min ^{-1}\right)$ & $119.63 \pm 16.69$ & $122.28 \pm 19.38$ & 0.60 & -0.11 \\
\hline Vertical oscillation mean $(\mathrm{cm})$ & $8.04 \pm 0.56$ & $7.96 \pm 0.54$ & 0.25 & 0.25 \\
\hline Vertical oscillation $_{\text {peak }}(\mathrm{cm})$ & $38.14 \pm 7.79$ & $37.39 \pm 11.22$ & 0.77 & 0.06 \\
\hline $\mathrm{GCT}_{\text {mean }}\left(\mathrm{m} \cdot \mathrm{s}^{-1}\right)$ & $538.10 \pm 68.84$ & $544.35 \pm 58.47$ & 0.53 & \\
\hline $\operatorname{GCT}_{\text {peak }}\left(\mathrm{m} \cdot \mathrm{s}^{-1}\right)$ & $1879.09 \pm 241.31$ & $1937.30 \pm 195.84$ & 0.41 & -0.17 \\
\hline Stiffness $_{\text {mean }}\left(\mathrm{KN} \cdot \mathrm{m}^{-1}\right)$ & $9.40 \pm 0.66$ & $9.16 \pm 0.53$ & $0.01 *$ & 0.57 \\
\hline \multicolumn{5}{|l|}{ Internal loads } \\
\hline $\mathrm{HR}_{\text {mean }}(\mathrm{bpm})$ & $160.48 \pm 12.75$ & $157.01 \pm 12.02$ & $0.01 *$ & 0.56 \\
\hline $\mathrm{HR}_{\text {peak }}(\mathrm{bpm})$ & $189.26 \pm 13.30$ & $183.00 \pm 11.05$ & $0.02 *$ & 0.50 \\
\hline Zone 1 (min) & $0.95 \pm 2.28$ & $0.41 \pm 1.77$ & 0.30 & 0.22 \\
\hline Zone 2 (min) & $1.50 \pm 3.51$ & $3.01 \pm 6.57$ & $0.04 *$ & -0.45 \\
\hline Zone 3 (min) & $9.23 \pm 7.29$ & $12.50 \pm 9.19$ & $0.00 * *$ & -0.69 \\
\hline Zone 4 (min) & $19.50 \pm 4.54$ & $22.18 \pm 8.09$ & $0.04 *$ & -0.46 \\
\hline Zone 5 (min) & $14.06 \pm 8.04$ & $10.30 \pm 7.04$ & $0.01 *$ & 0.62 \\
\hline TRIMP (AU) & $179.92 \pm 21.60$ & $184.19 \pm 25.54$ & 0.20 & -0.27 \\
\hline
\end{tabular}

Note. GCT = ground contact time; $\mathrm{HR}=$ heart rate; TRIMP $=$ training impulse. ${ }^{*}$ Significant differences between 1 st half and 2 nd half at $p<0.05 ;{ }^{*}$ Significant differences between 1 st half and 2 nd half at $p<0.01$.

The differences recorded by the FRs among 15 min periods in external and internal loads during the official matches are shown in Table 2. FRs covered more distance in the last 15 min period $(75-90 \mathrm{~min})$ than in any other $(p<0.01 ; \mathrm{d}=0.87$ to 1.45 , large). Moreover, in the 75-90 min period higher Power $_{\text {mean }}$ values were recorded than in the 0-15 $\min (p<0.01 ; \mathrm{d}=4.09$, large), 30-45 $\min (p<0.01 ; \mathrm{d}=4.14$, large $)$ and 60-75 $\min$ $\left(p<0.01 ; \mathrm{d}=4.28\right.$, large) periods. Higher values of Power $_{\text {mean }}$ were also recorded in the 15-30 $\mathrm{min}$ and 45-60 min periods compared to 0-15 $\mathrm{min}, 30-45 \mathrm{~min}$ and 60-75 $\mathrm{min}$ $(p<0.01 ; \mathrm{d}=4.34$ to 4.56 , large). Speed mean was higher in the $0-15 \mathrm{~min}$ period than in the 30-45 $\mathrm{min}, 60-75 \mathrm{~min}$ and $75-90 \mathrm{~min}$ periods ( $p<.01 ; \mathrm{d}=0.87$ to 0.89 , large). In addition,

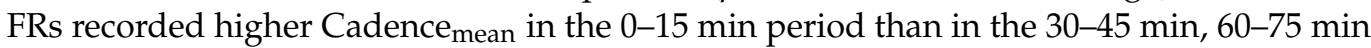
and 75-90 min periods ( $p<0.01 ; \mathrm{d}=0.77$ to 0.88 , moderate to large).

Regarding the internal load, a lower $\mathrm{HR}_{\text {mean }}$ was recorded in the 45-60 min period than in the 15-30 min period ( $p<0.05 ; \mathrm{d}=0.70$, moderate). Furthermore, lower $\mathrm{HR}_{\text {peak }}$ values were recorded in the 45-60 min than the $0-15 \mathrm{~min}(p<0.01 ; \mathrm{d}=0.79$, moderate $)$ and the 15-30 $\min \left(p<0.01 ; \mathrm{d}=0.68\right.$, moderate) periods. In addition, lower $\mathrm{HR}_{\text {peak }}$ values were recorded in the $60-75 \mathrm{~min}$ than the $0-15 \mathrm{~min}(p<0.05 ; \mathrm{d}=0.70$, moderate) period. FRs spent more time in zone 3 and zone 4 in the $75-90 \mathrm{~min}$ period than in the $15 \mathrm{~min}$ periods of the 1 st half ( $p<0.01 ; \mathrm{d}=0.64$ to 0.96 , moderate to large). FRs also spent more time in zone 5 in the 15-30 min period than in the 45-60 $\min (p<0.05 ; \mathrm{d}=0.68$, moderate) and the 60-75 $\mathrm{min}$ $(p<0.05 ; \mathrm{d}=0.68$, moderate) periods. Finally, FRs recorded higher TRIMP values in the 75-90 min period than in the rest of the 15 min periods of the match $(p<0.01 ; \mathrm{d}=1.20$ to 1.97 , large). FRs also recorded higher TRIMP in the 30-45 min than in the $45-60 \mathrm{~min}$ and $60-75$ min periods ( $p<0.05 ; \mathrm{d}=0.72$ to 0.78 , moderate). 
Table 2. Differences in external and internal match loads between 15 min periods in FRs

\begin{tabular}{|c|c|c|c|c|c|c|c|}
\hline & $0-15 \min$ & $15-30 \mathrm{~min}$ & $30-45 \mathrm{~min}$ & $45-60 \mathrm{~min}$ & $60-75 \mathrm{~min}$ & $75-90 \mathrm{~min}$ & $\begin{array}{l}\text { Periods Pair Comparison } \\
\text { (Cohen's d) }\end{array}$ \\
\hline $\begin{array}{l}\text { External loads } \\
\text { Distance }(\mathrm{km})\end{array}$ & $1.46 \pm 0.22$ & $1.43 \pm 0.12$ & $1.41 \pm 0.27$ & $1.38 \pm 0.18$ & $1.32 \pm 0.16$ & $1.66 \pm 0.24$ & $\begin{array}{c}0-15 \text { and } 75-90 ; \\
-0.87^{* *} \\
15-30 \text { and } 75-90 ; \\
-0.98^{* *} \\
30-45 \text { and } 75-90 ; \\
-1.07^{* *} \\
45-60 \text { and } 75-90 ; \\
-1.22^{* *} \\
60-75 \text { and } 75-90 ; \\
-1.45^{* *}\end{array}$ \\
\hline Power $_{\text {mean }}(\mathrm{W})$ & $127.08 \pm 15.91$ & $366.06 \pm 69.24$ & $124.00 \pm 15.81$ & $364.76 \pm 60.68$ & $116.71 \pm 11.91$ & $350.76 \pm 50.36$ & $\begin{array}{c}0-15 \text { and } 15-30 ; \\
-4.37^{* *} \\
0-15 \text { and } 45-60 ; \\
-4.34^{* *} \\
0-15 \text { and } 75-90 ; \\
-4.09^{* *} \\
15-30 \text { and } 30-45 ; \\
4.42^{* *} \\
15-30 \text { and } 60-75 ; \\
4.56^{* *} \\
30-45 \text { and } 45-60 ; \\
-4.40^{* *} \\
30-45 \text { and } 75-90 ; \\
-4.144^{* *} \\
45-60 \text { and } 60-75 ; \\
4.53^{* *} \\
60-75 \text { and } 75-90 ; \\
-4.28^{* *}\end{array}$ \\
\hline Power $_{\text {peak }}(\mathrm{W})$ & $366.06 \pm 69.24$ & $364.76 \pm 60.68$ & $350.76 \pm 50.36$ & $357.46 \pm 55.20$ & $350.67 \pm 83.50$ & $366.50 \pm 62.14$ & \\
\hline $\operatorname{Speed}_{\text {mean }}\left(\mathrm{km} \cdot \mathrm{h}^{-1}\right)$ & $7.43 \pm 0.80$ & $7.27 \pm 0.73$ & $6.92 \pm 0.62$ & $7.20 \pm 0.73$ & $6.93 \pm 0.73$ & $6.93 \pm 0.82$ & $\begin{array}{l}0-15 \text { and } 30-45 ; 0.89^{* *} \\
0-15 \text { and } 60-75 ; 0.88^{* *} \\
0-15 \text { and } 75-90 ; 0.87^{* *}\end{array}$ \\
\hline Speed $_{\text {peak }}\left(\mathrm{km} \cdot \mathrm{h}^{-1}\right)$ & $22.04 \pm 2.78$ & $21.86 \pm 1.78$ & $21.09 \pm 2.57$ & $21.82 \pm 1.83$ & $20.52 \pm 2.76$ & $21.51 \pm 2.58$ & \\
\hline Cadence $_{\text {mean }}\left(\right.$ steps $\cdot \min ^{-1}$ ) & $64.46 \pm 2.77$ & $63.24 \pm 2.50$ & $61.99 \pm 3.39$ & $63.57 \pm 2.42$ & $61.97 \pm 2.86$ & $61.66 \pm 2.35$ & $\begin{array}{l}0-15 \text { and } 30-45 ; 0.77^{* *} \\
0-15 \text { and } 60-75 ; 0.78^{* *} \\
0-15 \text { and } 75-90 ; 0.88^{* *}\end{array}$ \\
\hline Cadence $_{\text {peak }}\left(\right.$ steps $\left.\cdot \mathrm{min}^{-1}\right)$ & $111.50 \pm 14.44$ & $107.11 \pm 11.50$ & $106.59 \pm 15.08$ & $108.15 \pm 11.72$ & $107.46 \pm 16.18$ & $113.50 \pm 18.88$ & \\
\hline Vertical oscillation $_{\text {mean }}(\mathrm{cm})$ & $8.13 \pm 0.74$ & $8.01 \pm 0.51$ & $7.94 \pm 0.64$ & $7.94 \pm 0.50$ & $8.08 \pm 0.76$ & $7.85 \pm 0.64$ & \\
\hline Vertical oscillation $_{\text {peak }}(\mathrm{cm})$ & $33.18 \pm 8.94$ & $28.87 \pm 7.28$ & $30.00 \pm 9.07$ & $30.72 \pm 7.08$ & $30.73 \pm 8.47$ & $33.02 \pm 12.24$ & \\
\hline $\mathrm{GCT}_{\text {mean }}\left(\mathrm{m} \cdot \mathrm{s}^{-1}\right)$ & $517.98 \pm 75.59$ & $552.89 \pm 67.08$ & $544.20 \pm 101.73$ & $530.29 \pm 77.86$ & $551.47 \pm 65.88$ & $549.58 \pm 64.44$ & \\
\hline $\mathrm{GCT}_{\text {peak }}\left(\mathrm{m} \cdot \mathrm{s}^{-1}\right)$ & $1761.65 \pm 301.89$ & $1676.87 \pm 179.90$ & $1671.04 \pm 169.74$ & $1718.96 \pm 239.28$ & $1725.91 \pm 219.34$ & $1826.22 \pm 209.85$ & \\
\hline
\end{tabular}


Table 2. Cont.

\begin{tabular}{|c|c|c|c|c|c|c|c|}
\hline & $0-15 \min$ & $15-30 \mathrm{~min}$ & $30-45 \min$ & $45-60 \mathrm{~min}$ & $60-75 \min$ & $75-90 \mathrm{~min}$ & $\begin{array}{c}\text { Periods Pair Comparison } \\
\text { (Cohen's d) }\end{array}$ \\
\hline Stiffness $_{\text {mean }}\left(\mathrm{KN} \cdot \mathrm{m}^{-1}\right)$ & $9.44 \pm 0.87$ & $9.40 \pm 0.78$ & $9.31 \pm 0.60$ & $9.18 \pm 0.71$ & $9.22 \pm 0.65$ & $9.08 \pm 0.60$ & \\
\hline Stiffness peak $_{\text {pN }}\left(\mathrm{K} \mathrm{m}^{-1}\right)$ & $28.21 \pm 7.87$ & $26.35 \pm 7.93$ & $27.23 \pm 7.89$ & $26.93 \pm 8.18$ & $26.08 \pm 5.12$ & $26.43 \pm 7.82$ & \\
\hline $\begin{array}{l}\text { Internal loads } \\
\mathrm{HR}_{\text {mean }}(\mathrm{bpm})\end{array}$ & $160.22 \pm 14.35$ & $162.14 \pm 12.30$ & $159.14 \pm 14.41$ & $156.29 \pm 12.75$ & $157.00 \pm 11.52$ & $157.58 \pm 13.05$ & $15-30$ and $45-60 ; 0.70 *$ \\
\hline $\mathrm{HR}_{\text {peak }}(\mathrm{bpm})$ & $185.83 \pm 14.65$ & $184.70 \pm 12.84$ & $180.65 \pm 10.86$ & $177.52 \pm 12.84$ & $178.44 \pm 10.74$ & $181.52 \pm 10.38$ & $\begin{array}{l}0-15 \text { and } 45-60 ; 0.79^{* *} \\
0-15 \text { and } 60-75 ; 0.70^{*} \\
15-30 \text { and } 45-60 ; 0.68^{*}\end{array}$ \\
\hline Zone 1 (min) & $0.54 \pm 1.74$ & $0.10 \pm 0.48$ & $0.31 \pm 1.42$ & $0.19 \pm 0.80$ & $0.10 \pm 0.42$ & $0.12 \pm 0.56$ & \\
\hline Zone 3 (min) & $3.06 \pm 2.41$ & $2.62 \pm 2.71$ & $3.54 \pm 2.97$ & $4.01 \pm 2.98$ & $3.72 \pm 3.09$ & $4.77 \pm 3.77$ & $\begin{array}{c}0-15 \text { and } 75-90 \\
-0.76^{* *} \\
15-30 \text { and } 75-90 \\
-0.96^{* *}\end{array}$ \\
\hline Zone 4 (min) & $6.10 \pm 1.93$ & $6.80 \pm 1.98$ & $6.60 \pm 2.36$ & $6.78 \pm 2.49$ & $7.12 \pm 2.83$ & $8.29 \pm 3.67$ & $\begin{array}{c}0-15 \text { and } 75-90 \\
-0.82{ }^{* *} \\
30-45 \text { and } 75-90 \\
-0.64^{*}\end{array}$ \\
\hline Zone 5 (min) & $4.52 \pm 2.74$ & $4.85 \pm 3.20$ & $4.69 \pm 3.25$ & $2.94 \pm 2.49$ & $2.94 \pm 2.06$ & $4.42 \pm 3.60$ & $\begin{array}{l}15-30 \text { and } 45-60 ; 0.68 * \\
15-30 \text { and } 60-75 ; 0.68 \text { * }\end{array}$ \\
\hline
\end{tabular}


The differences recorded by ARs between the 1st half and 2nd half in external and internal loads during official matches are shown in Table 3. In ARs, no significant decrease of external load was observed in the 2nd half except in Vertical Oscillation mean $(p<0.01$; $\mathrm{d}=0.42$, moderate). However, higher values of Cadence $_{\text {peak }}$ were recorded in the 2 nd half $(p<0.05 ; d=0.35$, small). Despite no significant differences being found in most of the analyzed variables of external load between the 1st and 2nd half, when internal load is studied, ARs showed lower $\mathrm{HR}_{\text {mean }}$ values in the 2nd half ( $p<0.01 ; \mathrm{d}=0.63$, moderate) and they also spent less time in zone $5(p<0.01 ; \mathrm{d}=0.41$, small). On the other hand, ARs spent more time in the 2 nd half than in the 1 st half in zones 1 and $2(p<0.01 ; d=0.42$ to 0.48 , small).

Table 3. Differences in external and internal match loads between 1st half and 2nd half in ARs.

\begin{tabular}{|c|c|c|c|c|}
\hline & 1st Half & 2nd Half & $p<$ Value & Cohen's d \\
\hline \multicolumn{5}{|l|}{ External loads } \\
\hline Distance $(\mathrm{km})$ & $1995 \pm 0.46$ & $1924 \pm 0.56$ & 0.46 & 0.11 \\
\hline Power $_{\text {mean }}(\mathrm{W})$ & $90.90 \pm 10.45$ & $88.77 \pm 8.79$ & 0.16 & 0.21 \\
\hline Power $_{\text {peak }}(\mathrm{W})$ & $322.35 \pm 39.70$ & $322.22 \pm 46.64$ & 0.99 & 0.00 \\
\hline Speed $_{\text {mean }}\left(\mathrm{km} \cdot \mathrm{h}^{-1}\right)$ & $5.84 \pm 0.53$ & $5.75 \pm 0.50$ & 0.25 & 0.17 \\
\hline Speed $_{\text {peak }}\left(\mathrm{km} \cdot \mathrm{h}^{-1}\right)$ & $20.86 \pm 2.02$ & $20.78 \pm 2.42$ & 0.84 & 0.03 \\
\hline Cadence $_{\text {mean }}\left(\right.$ steps $\cdot \min ^{-1}$ ) & $56.40 \pm 3.64$ & $55.61 \pm 3.50$ & 0.06 & 0.29 \\
\hline Cadence $_{\text {peak }}\left(\right.$ steps $\left.\cdot \min ^{-1}\right)$ & $127.85 \pm 19.45$ & $137.56 \pm 23.48$ & $0.02 *$ & -0.35 \\
\hline Vertical oscillation mean $(\mathrm{cm})$ & $7.71 \pm 0.77$ & $7.41 \pm 0.52$ & $0.01 *$ & 0.42 \\
\hline Vertical oscillation $_{\text {peak }}(\mathrm{cm})$ & $39.57 \pm 8.56$ & $37.18 \pm 10.31$ & 0.25 & 0.17 \\
\hline $\mathrm{GCT}_{\text {mean }}\left(\mathrm{m} \cdot \mathrm{s}^{-1}\right)$ & $391.17 \pm 204.35$ & $366.05 \pm 231.16$ & 0.20 & 0.20 \\
\hline $\operatorname{GCT}_{\text {peak }}\left(\mathrm{m} \cdot \mathrm{s}^{-1}\right)$ & $2015.74 \pm 223.34$ & $1924 \pm 348.09$ & 0.10 & 0.25 \\
\hline Stiffness $_{\text {mean }}\left(\mathrm{KN} \cdot \mathrm{m}^{-1}\right)$ & $8.69 \pm 0.59$ & $8.61 \pm 0.67$ & 0.19 & 0.20 \\
\hline $\begin{array}{c}\text { Stiffness } \\
\text { peak }\left(\mathrm{KN} \cdot \mathrm{m}^{-1}\right) \\
\text { Internal loads }\end{array}$ & $30.48 \pm 11.20$ & $32.16 \pm 11.80$ & 0.51 & -0.10 \\
\hline $\mathrm{HR}_{\text {mean }}(\mathrm{bpm})$ & $136.86 \pm 18.46$ & $131.92 \pm 18.26$ & $0.00 * *$ & 0.63 \\
\hline $\mathrm{HR}_{\text {peak }}(\mathrm{bpm})$ & $179.09 \pm 23.08$ & $177.50 \pm 21.51$ & 0.56 & 0.09 \\
\hline Zone 1 (min) & $4.69 \pm 6.04$ & $6.88 \pm 7.21$ & $0.00 * *$ & -0.48 \\
\hline Zone 2 (min) & $10.22 \pm 8.18$ & $12.52 \pm 8.38$ & $0.01 *$ & -0.42 \\
\hline Zone 3 (min) & $12.97 \pm 6.36$ & $14.14 \pm 6.94$ & 0.25 & -0.17 \\
\hline Zone 4 (min) & $11.82 \pm 8.40$ & $10.76 \pm 9.01$ & 0.21 & 0.19 \\
\hline Zone 5 (min) & $4.68 \pm 5.30$ & $2.86 \pm 3.41$ & $0.01 *$ & 0.41 \\
\hline TRIMP (AU) & $134.77 \pm 40.30$ & $127.71 \pm 43.16$ & 0.16 & 0.21 \\
\hline
\end{tabular}

Note. $\mathrm{GCT}=$ ground contact time; HR = heart rate; TRIMP = training impulse. * Significant differences between 1 st half and 2 nd half at $p<0.05 ;{ }^{* *}$ Significant differences between 1 st half and 2 nd half at $p<0.01$.

The differences recorded by ARs among 15 min periods in external and internal loads during the official matches are shown in Table 4 . The periods in which more distance was covered were $30-45 \min (p<0.01 ; \mathrm{d}=0.59$ to 0.62 , moderate) and 75-90 $\mathrm{min}(p<0.01$; $\mathrm{d}=0.51$ to 0.97 , moderate to large). More distance was covered also in 0-15 min compared to $45-60 \min (p<0.05 ; \mathrm{d}=0.45$, small). Moreover, in the $0-15 \mathrm{~min}$ period ARs recorded higher Power mean, than in the 30-45 min, 60-75 min and 75-90 min periods $(p<0.01$; $\mathrm{d}=0.53$ to 0.58 , moderate); higher Speed $_{\text {mean }}$ than in 30-45 $\mathrm{min}$ and 60-75 $\mathrm{min}(p<0.05$; $\mathrm{d}=0.50$ to 0.55 , small to moderate), higher Cadence mean $_{\text {than }}$ in 15-30 min, 30-45 min, 60-75 min and 75-90 min periods ( $p<0.01 ; \mathrm{d}=0.57$ to 0.75 , moderate) and higher Vertical oscillation $_{\text {mean }}$ than in the 60-75 min and 75-90 min periods $(p<0.05 ; \mathrm{d}=0.44$ to 0.60 , small to moderate). In addition, the 45-60 min period also showed higher Cadence mean values than the 30-45 $\mathrm{min}, 60-75 \mathrm{~min}$ and $75-90 \mathrm{~min}$ periods $(p<0.05 ; \mathrm{d}=0.44$ to 0.50 , small). Finally, in the 45-60 min period lower GCT $_{\text {mean }}$ values were shown than in the 30-45 min and 75-90 min periods ( $p<0.01 ; \mathrm{d}=0.52$ to 0.62 , moderate), and lower $\mathrm{GCT}_{\text {peak }}$ values than in the $0-15 \mathrm{~min}, 30-45 \mathrm{~min}$ and $75-90 \mathrm{~min}$ periods ( $p<0.05 ; \mathrm{d}=0.45$ to 0.47 , small). 
Table 4. Differences in external and internal match loads between 15 min periods in ARs

\begin{tabular}{|c|c|c|c|c|c|c|c|}
\hline & 0-15 min & $15-30 \mathrm{~min}$ & $30-45 \min$ & $45-60 \mathrm{~min}$ & $60-75 \min$ & $75-90 \mathrm{~min}$ & $\begin{array}{c}\text { Periods Pair Comparison } \\
\text { (Cohen's d) }\end{array}$ \\
\hline External loads & $0.67 \pm 0.22$ & $0.61 \pm 0.19$ & $0.71 \pm 0.18$ & $0.56 \pm 0.25$ & $0.57 \pm 0.19$ & $0.80 \pm 0.22$ & $\begin{array}{c}0-15 \text { and } 45-60 ; 0.45^{*} \\
0-15 \text { and } 75-90 ; \\
-0.51^{* *} \\
15-30 \text { and } 75-90 ; \\
-0.76^{* *} \\
30-45 \text { and } 45-60 ; 0.62 * * \\
30-45 \text { and } 60-75 ; 0.59 * * \\
45-60 \text { and } 75-90 ; \\
-0.97 * * \\
60-75 \text { and } 75-90 ; \\
-0.94 * *\end{array}$ \\
\hline Power $_{\text {mean }}(W)$ & $95.49 \pm 15.73$ & $89.50 \pm 10.85$ & $87.88 \pm 10.59$ & $91.68 \pm 13.33$ & $87.20 \pm 13.40$ & $87.69 \pm 10.34$ & $\begin{array}{l}0-15 \text { and } 30-45 ; 0.533^{* *} \\
0-15 \text { and } 60-75 ; 0.58^{* *} \\
0-15 \text { and } 75-90 ; 0.54 \text { ** }\end{array}$ \\
\hline Power peak $_{(W)}$ & $295.26 \pm 45.84$ & $290.06 \pm 47.47$ & $276.52 \pm 43.30$ & $274.50 \pm 57.70$ & $269.37 \pm 56.49$ & $295.11 \pm 47.96$ & \\
\hline $\operatorname{Speed}_{\text {mean }}\left(\mathrm{km} \cdot \mathrm{h}^{-1}\right)$ & $6.07 \pm 0.78$ & $5.77 \pm 0.48$ & $5.70 \pm 0.63$ & $5.85 \pm 0.70$ & $5.66 \pm 0.73$ & $5.75 \pm 0.63$ & $\begin{array}{l}0-15 \text { and } 30-45 ; 0.50 * \\
0-15 \text { and } 60-75 ; 0.55 \text { ** }\end{array}$ \\
\hline Speed $_{\text {peak }}\left(\mathrm{km} \cdot \mathrm{h}^{-1}\right)$ & $19.38 \pm 2.86$ & $18.89 \pm 2.52$ & $18.37 \pm 2.24$ & $18.05 \pm 3.26$ & $18.08 \pm 3.15$ & $19.33 \pm 2.41$ & \\
\hline Cadence $_{\text {mean }}\left(\right.$ steps per min $^{-1}$ ) & $58.42 \pm 4.45$ & $55.80 \pm 4.04$ & $55.21 \pm 4.27$ & $57.29 \pm 4.49$ & $54.99 \pm 4.16$ & $55.26 \pm 4.68$ & $\begin{array}{c}0-15 \text { and } 15-30 ; 0.57^{* *} \\
0-15 \text { and } 30-45 ; 0.70^{* *} \\
0-15 \text { and } 60-75 ; 0.75 * * \\
0-15 \text { and } 75-90 ; 0.69^{* *} \\
30-45 \text { and } 45-60 ; \\
-0.46^{*} \\
45-60 \text { and } 60-75 ; 0.50^{*} \\
45-60 \text { and } 75-90 ; 0.44^{*}\end{array}$ \\
\hline Cadence $_{\text {peak }}\left(\right.$ steps per min ${ }^{-1}$ ) & $115.28 \pm 16.85$ & $113.50 \pm 18.47$ & $111.96 \pm 16.19$ & $119.96 \pm 22.90$ & $113.44 \pm 23.08$ & $118.87 \pm 22.74$ & \\
\hline Vertical oscillation $_{\text {mean }}(\mathrm{cm})$ & $7.90 \pm 0.97$ & $7.61 \pm 1.05$ & $7.52 \pm 0.96$ & $7.52 \pm 0.71$ & $7.43 \pm 0.81$ & $7.26 \pm 0.70$ & $\begin{array}{l}0-15 \text { and } 60-75 ; 0.44^{*} \\
0-15 \text { and } 75-90 ; 0.60^{* *}\end{array}$ \\
\hline Vertical oscillation $_{\text {peak }}(\mathrm{cm})$ & $34.36 \pm 10.16$ & $29.91 \pm 8.47$ & $31.61 \pm 9.72$ & $30.18 \pm 11.01$ & $30.37 \pm 11.00$ & $28.99 \pm 7.27$ & \\
\hline $\mathrm{GCT}_{\text {mean }}\left(\mathrm{m} \cdot \mathrm{s}^{-1}\right)$ & $339.127 \pm 109.76$ & $353.310 \pm 118.09$ & $387.593 \pm 117.70$ & $294.224 \pm 141.42$ & $334.895 \pm 119.22$ & $372.590 \pm 106.11$ & $\begin{array}{c}30-45 \text { and } 45-60 ; 0.62 * * \\
45-60 \text { and } 75-90 ; \\
-0.52 * *\end{array}$ \\
\hline $\mathrm{GCT}_{\text {peak }}\left(\mathrm{m} \cdot \mathrm{s}^{-1}\right)$ & $1822.00 \pm 232.90$ & $1772.26 \pm 252.74$ & $1816.74 \pm 260.16$ & $1651.13 \pm 319.11$ & $1729.61 \pm 319.35$ & $1814.09 \pm 368.58$ & $\begin{array}{c}0-15 \text { and } 45-60 ; 0.47^{*} \\
30-45 \text { and } 45-60 ; 0.46^{*} \\
45-60 \text { and } 75-90 ; \\
-0.45^{*}\end{array}$ \\
\hline Stiffness mean $\left(\mathrm{KN} \cdot \mathrm{m}^{-1}\right)$ & $8.76 \pm 0.75$ & $8.60 \pm 0.78$ & $8.58 \pm 0.74$ & $8.54 \pm 0.97$ & $8.50 \pm 0.84$ & $8.73 \pm 0.94$ & \\
\hline Stiffness $_{\text {peak }}\left(\mathrm{KN} \cdot \mathrm{m}^{-1}\right)$ & $23.25 \pm 10.32$ & $21.19 \pm 9.60$ & $21.05 \pm 9.76$ & $22.30 \pm 11.66$ & $20.56 \pm 9.17$ & $24.87 \pm 10.95$ & \\
\hline
\end{tabular}


Table 4. Cont.

\begin{tabular}{|c|c|c|c|c|c|c|c|}
\hline & 0-15 min & $15-30 \mathrm{~min}$ & $30-45 \mathrm{~min}$ & $45-60 \mathrm{~min}$ & $60-75 \min$ & $75-90 \mathrm{~min}$ & $\begin{array}{c}\text { Periods Pair Comparison } \\
\text { (Cohen's d) }\end{array}$ \\
\hline $\begin{array}{l}\text { Internal loads } \\
\mathrm{HR}_{\text {mean }}(\mathrm{bpm})\end{array}$ & $139.76 \pm 19.67$ & $135.83 \pm 18.22$ & $135.44 \pm 19.90$ & $131.04 \pm 20.71$ & $130.97 \pm 18.47$ & $133.21 \pm 18.11$ & $\begin{array}{l}0-15 \text { and } 45-60 ; 0.83^{* *} \\
0-15 \text { and } 60-75 ; 0.83^{* *} \\
0-15 \text { and } 75-90 ; 0.62^{* *} \\
15-30 \text { and } 45-60 ; 0.45^{*} \\
15-30 \text { and } 60-75 ; 0.46^{*}\end{array}$ \\
\hline $\mathrm{HR}_{\text {peak }}(\mathrm{bpm})$ & $173.91 \pm 22.52$ & $168.70 \pm 18.64$ & $168.87 \pm 21.26$ & $168.11 \pm 21.30$ & $166.02 \pm 20.18$ & $170.48 \pm 21.63$ & $0-15$ and $60-75 ; 0.44^{*}$ \\
\hline Zone 1 (min) & $1.22 \pm 1.82$ & $1.72 \pm 2.33$ & $1.82 \pm 2.52$ & $2.21 \pm 2.76$ & $2.16 \pm 2.42$ & $2.36 \pm 2.90$ & $\begin{array}{r}0-15 \text { and } 45-60 ; \\
-0.48^{*} \\
0-15 \text { and } 60-75 ; \\
-0.46^{*} \\
0-15 \text { and } 75-90 ; \\
-0.56^{* *}\end{array}$ \\
\hline Zone 2 (min) & $3.00 \pm 3.06$ & $3.59 \pm 2.82$ & $3.83 \pm 3.02$ & $3.66 \pm 2.52$ & $4.05 \pm 3.01$ & $4.95 \pm 3.55$ & $\begin{array}{c}0-15 \text { and } 60-75 ; \\
-0.44^{*} \\
0-15 \text { and } 75-90 ; \\
-0.81^{* *} \\
15-30 \text { and } 75-90 ; \\
-0.56^{* *} \\
30-45 \text { and } 75-90 ; \\
-0.46^{*} \\
45-60 \text { and } 75-90 ; \\
-0.54^{* *}\end{array}$ \\
\hline Zone 3 (min) & $4.14 \pm 2.62$ & $4.11 \pm 2.44$ & $4.93 \pm 2.51$ & $4.23 \pm 2.38$ & $4.41 \pm 2.51$ & $5.83 \pm 2.78$ & $\begin{array}{c}0-15 \text { and } 75-90 ; \\
-0.66^{* *} \\
15-30 \text { and } 75-90 ; \\
-0.67^{* *} \\
45-60 \text { and } 75-90 ; \\
-0.62^{* *} \\
60-75 \text { and } 75-90 ; \\
-0.56^{* *} \\
\end{array}$ \\
\hline Zone 4 (min) & $4.17 \pm 3.05$ & $3.72 \pm 2.78$ & $4.00 \pm 3.23$ & $3.18 \pm 2.82$ & $3.20 \pm 2.77$ & $4.23 \pm 3.76$ & $\begin{array}{c}45-60 \text { and } 75-90 ; \\
-0.46^{*} \\
60-75 \text { and } 75-90 ; \\
-0.45^{*}\end{array}$ \\
\hline Zone 5 (min) & $1.99 \pm 2.38$ & $1.52 \pm 1.89$ & $1.21 \pm 1.57$ & $0.95 \pm 1.45$ & $0.65 \pm 0.97$ & $1.05 \pm 1.21$ & $\begin{array}{l}0-15 \text { and } 30-45 ; 0.47^{*} \\
0-15 \text { and } 45-60 ; 0.62^{* *} \\
0-15 \text { and } 60-75 ; 0.81^{* *} \\
0-15 \text { and } 75-90 ; 0.57^{* *} \\
15-30 \text { and } 60-75 ; 0.52^{* *}\end{array}$ \\
\hline
\end{tabular}


Table 4. Cont.

0-15 min

15-30 min

30-45 min

45-60 min

60-75 min

75-90 min

$39.56 \pm 12.53$
$39.68 \pm 14.34$
$43.72 \pm 13.20$
$46.29 \pm 13.56$
$51.89 \pm 14.99$
Periods Pair Comparison (Cohen's d)

$0-15$ and $45-60 ; 0.75$ *

$0-15$ and $60-75 ; 0.76$ **

$0-15$ and $75-90 ;-0.63$

$15-30$ and $45-60 ; 0.46$

$15-30$ and $60-75 ; 0.47$

$15-30$ and $75-90$

$30-45$ and $45-60 ; 0.75 * *$

$30-45$ and $60-75 ; 0.76$ **

$30-45$ and $75-90$

$-0.63^{* *}$

45-60 and 75-90;

-1.38 **
$60-75$ and $75-90$ 
When internal load is observed, ARs recorded lower $\mathrm{HR}_{\text {mean }}$ values in the $45-60 \mathrm{~min}$, 60-75 min and 75-90 min periods than in the 0-15 min period $(p<0.01 ; \mathrm{d}=0.63$ to 0.83 , moderate to large). $\mathrm{HR}_{\text {mean }}$ lower values were also recorded in the 45-60 min and 60-75 min periods than in the $15-30$ min period ( $p<0.05 ; \mathrm{d}=0.45$ to 0.46 , small). In addition, the 60-75 min period recorded a lower $\mathrm{HR}_{\text {peak }}$ than the $0-15 \mathrm{~min}$ period $(p<0.05 ; \mathrm{d}=0.44$, small). ARs spent more time in zones 1 and 2 , as the match progressed $(p<0.05 ; \mathrm{d}=0.44$ to 0.81 , small to large). Moreover, ARs were in zone 3 more times in the 75-90 min period than in the previous 15 min periods ( $p<0.01 ; \mathrm{d}=0.46$ to 0.67 , small to moderate) and also spent more time in zone 4 during the 75-90 min period than in the 45-60 min and 60-75 min periods $(p<0.05 ; \mathrm{d}=0.45$ to 0.46 , small). In contrast to zones 1 and 2 , ARs spent less time in zone 5 as the match went on, recording more time in zone 5 during the $0-15$ min period than in the 30-45 $\mathrm{min}, 45-60 \mathrm{~min}, 60-75 \mathrm{~min}$ and 75-90 min periods $(p<0.05 ; \mathrm{d}=0.47$ to 0.81 , small to large). They also spent less time in zone 5 during the $60-75$ min period than in the 15-30 min period ( $p<0.01 ; \mathrm{d}=0.52$, moderate).

\section{Discussion}

There are studies that have analyzed the differences in the external and internal load between the 1st and 2nd half or between shorter periods in FRs and ARs during match play $[13,14,22,23]$. However, this is the first study to analyze the differences in external and internal load among 15 min periods in amateur match officials. Considering that there are thousands of amateur official matches officiated by amateur referees, a more exhaustive knowledge of the evolution of the external and internal load during match play could be interesting in order to adjust the training sessions for optimizing match officials' performance.

The results of this study showed that FRs recorded lower Power mean, Speed $_{\text {mean, }}$ Cadence $_{\text {mean }}$ and Stiffness mean during the 2 nd half in comparison to the 1st half, but no differences were found in Vertical oscillation mean $_{\text {and }} \mathrm{GCT}_{\text {mean. These results are in }}$ concordance with other studies which found a lower external load during the 2nd half in international match officials [23,25]. Similarly, although FRs spent more time in zones 2, 3 and 4 during the 2 nd half compared to the 1st half, they recorded a significantly lower $\mathrm{HR}_{\text {mean }}, \mathrm{HR}_{\text {peak }}$ and time spent in zone 5. Again, these results coincide with previous literature in national and international match officials [14,26]. One of the main contributions of the present study is that, despite a decrease being found in the external load average variables, no differences were found between any external load peak variables. These results show that FRs are able to perform similar peak values during the 2nd half compared to the 1st half but are not capable of maintaining mean external load. This was corroborated by Costa et al. [33] reporting that FRs' mean speed decreases during the 2 nd half but they can maintain a similar maximum speed during match play. In future studies it would be necessary to analyze whether the decrease in the external and internal load during the 2nd half in FRs is due to neuromuscular and/or cardiovascular fatigue or to other factors derived from the match.

To achieve a more in-depth analysis of external and internal load variations in the 1st and 2nd half, a study of shorter periods can provide more information about what happens during match play $[13,15,27,34]$. Our results showed highest Speed $_{\text {mean }}$ and Cadence $_{\text {mean }}$ at the beginning of the match (0-15 $\left.\mathrm{min}\right)$ that were significantly higher than in the 30-45 $\mathrm{min}, 60-75 \mathrm{~min}$ and 75-90 min time-periods. These results are in concordance with previous studies in which the first 15 min periods revealed the greatest external loads during international matches $[13,15]$. On the other hand, FRs covered more total distance during the last $15 \mathrm{~min}$ of the match (75-90 $\mathrm{min}$ ) in comparison to other $15 \mathrm{~min}$ periods of

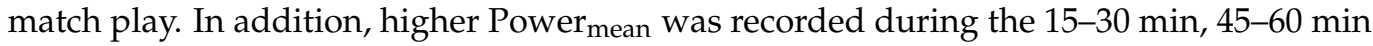
and 75-90 min periods with respect to other 15 min periods. Nevertheless, no significant differences were found in Vertical oscillation mean $_{\text {, GCT }}$ mean and Stiffness mean $_{\text {during }} 15$ min time periods across match play. Regarding internal load, although the variables decrease as the match progresses, our results also showed that the time in zones 3,4 and 5 was longer 
than in previous 15 min periods during the 2 nd half. These findings could be explained by higher match intensity caused by the increase in the number of missed passes [35,36] which could translate into more transitions involving more disordered match play, so FRs have to be continuously close to play in order to be more successful making key decisions [37].

Since the ARs perform specific movement patterns during match play, it is interesting to know the variations in the external and internal load throughout official matches. Our results showed that there were no significant differences in the variation of external loads between halves in ARs, with the exception of Vertical oscillation mean $_{\text {and }}$ Cadence peak decreasing and increasing during the 2 nd half, respectively. Related to variation in internal load across matches, a decrease was observed in the $\mathrm{HR}_{\text {mean }}$ and time spent in zone 5 during the 2 nd half. Otherwise, time spent in zones 1 and 2 increased during the 2nd half in ARs which is concordant with the study of Castillo et al. [6] with national ARs. Overall, the lack of differences in external loads between halves could be due to the different roles of ARs during match play with respect to FRs, who are exposed to greater external loads because they have to cover more ground $[9,27]$. On the other hand, according to the differences reported in internal load, it could be that ARs spent less time moving backwards and sideways [27] which create more metabolic demand [38] maintaining external load similar to the 1 st half but increasing the internal load during the 2 nd half.

To understand the external and internal loads as the match progresses in ARs, a 15 min time-period analysis is necessary. Our results showed that ARs recorded the highest values of Power mean, Speed $_{\text {mean, }}$ Cadence mean $_{\text {and Vertical oscillation }}$ mean during 0-15 min period. However, it was observed that ARs covered more total distance during the last 15 min of both halves (i.e., the 30-45 min and 75-90 min periods) than other 15 min periods. Similarly, to the external load, when internal load is observed, the higher values of $H_{\text {mean }}$ and time spent in zone 5 were recorded in 0-15 min and were significantly higher than in all $15 \mathrm{~min}$ periods of the 2 nd half ( $45-60 \mathrm{~min}, 60-75 \mathrm{~min}$ and $75-90 \mathrm{~min}$ ) ( $p<0.05 ; \mathrm{d}=0.45$ to 0.83 , small to large). As occurs with FRs, it seems that the last minutes of the match imply that soccer players miss more passes [35] which could cause more transitions in play in which ARs have to cover greater distances.

In the present study it was not possible to analyze the reasons for the variation in the internal or external load in FRs and ARs in the different periods of the match. For this reason, it would be interesting to analyze in future studies what these reasons might be and whether they might be due, among other things, to motivation, the result of the match, fatigue or other factors.

\section{Conclusions}

The results of this study show that both FRs' and ARs' match load decreases during the match except for the last 15 min period, in which FRs and ARs covered more distance and FRs also produced higher Power mean. Results suggest that match load decreases as the match progresses probably caused by neuromuscular fatigue. However, in the last 15 min some match load variables increased in both FRs' and ARs' groups due to a higher number of attacks and transitions increasing their match load.

Author Contributions: Conceptualization, D.C. and U.F.-L.; methodology, D.C.; software, R.C. and E.O.; formal analysis, D.C., E.O., I.M.-A. and U.F.-L.; investigation, E.O., I.M.-A. and R.C.; data curation, E.O. and D.C.; writing - original draft preparation, E.O.; writing-review and editing, D.C, I.M.-A., R.C. and U.F.-L.; visualization, D.C.; supervision, D.C. and U.F.-L.; project administration, E.O. All authors have read and agreed to the published version of the manuscript.

Funding: This research received no external funding.

Institutional Review Board Statement: The study was conducted in accordance with the Declaration of Helsinki, and approved by the Ethics Committee (CEISH) of The University of the Basque Country (UPV/EHU) (Code: M10/2018/289).

Informed Consent Statement: Informed consent was obtained from all subjects involved in the study. 
Data Availability Statement: Author's property.

Acknowledgments: The authors gratefully acknowledge the support of a Spanish government subproject Mixed method approach on performance analysis (in training and competition) in elite and academy sport (PGC2018-098742-B-C33) (2019-2021) del Ministerio de Ciencia, Innovación y Universidades (MCIU), la Agencia Estatal de Investigación (AEI) y el Fondo Europeo de Desarrollo Regional (FEDER)), that is part of the coordinated project, New approach of research in physical activity and sport from mixed methods' perspective (NARPAS_MM) (SPGC201800X098742CV0).

Conflicts of Interest: The authors declare no conflict of interest.

\section{References}

1. D'Ottavio, S.; Castagna, C. Analysis of match play activities in elite soccer referees during actual match play. J. Strength Cond. Res. 2001, 15, 167-171. [CrossRef]

2. D'Ottavio, S.; Castagna, C. Physiological load imposed on elite soccer referees during actual match play. J. Sports Med. Phys. Fitness 2001, 41, 27-32. [PubMed]

3. Mallo, J.; Gonzalez Frutos, P.; Juárez, D.; Navarro, E. Effect of Positioning on the accuracy of decision making of association football top-class referees and assistant referees during competitive matches. J. Sports Sci. 2012, 30, 1437-1445. [CrossRef]

4. Rebole, M.; Castillo, D.; Yanci, J. Relationship between the cardiovascular capacity and repeated sprint ability in high-standard soccer referees. Rev. Iberoam. Cienc. Act. Física Deport. 2017, 5, 49-64.

5. Yanci, J.; Los Arcos, A.; Grande, I.; Casajús, J.A. Change of direction ability test differentiates higher level and lower level soccer referees. Biol. Sport 2016, 33, 173-177. [CrossRef]

6. Castillo, D.; Yanci, J.; Casajús, J.A.; Cámara, J. Physical fitness and physiological characteristics of soccer referees. Sci. Sport. 2016, 31, 27-35. [CrossRef]

7. Castillo, D.; Castagna, C.; Camara, J.; Iturricastillo, A.; Yanci, J. Influence of team's rank on soccer referees' external and internal match loads during official matches. J. Strength Cond. Res. 2018, 32, 1715-1722. [CrossRef]

8. Castillo, D.; Yanci, J.; Cámara, J.; Weston, M. The influence of soccer match play on physiological and physical performance measures in soccer referees and assistant referees. J. Sports Sci. 2016, 34, 557-563. [CrossRef]

9. Castillo, D.; Weston, M.; McLaren, S.J.; Cámara, J.; Yanci, J. Relationships between internal and external match-load indicators in soccer match officials. Int. J. Sports Physiol. Perform. 2017, 12, 922-927. [CrossRef]

10. Castillo, D.; Cámara, J.; Lozano, D.; Berzosa, C.; Yanci, J. The association between physical performance and match-play activities of field and assistants soccer referees. Res. Sport. Med. 2019, 27, 283-297. [CrossRef]

11. Ishihara, Y.; Naito, H.; Ozaki, H.; Yoshimura, M. Aerobic fitness relation to match performance of Japanese soccer referees. Footb. Sci. 2015, 12, 91-97.

12. Castillo, D.; Cámara, J.; Sedano, S.; Yanci, J. Impact of official matches on soccer referees' horizontal-jump performance. Sci. Med. Footb. 2017, 1, 145-150. [CrossRef]

13. Krustrup, P.; Helsen, W.; Randers, M.B.; Christensen, J.F.; Macdonald, C.; Rebelo, A.N.; Bangsbo, J. Activity profile and physical demands of football referees and assistant referees in international games. J. Sports Sci. 2009, 27, 1167-1176. [CrossRef] [PubMed]

14. Castillo, D.; Camara, J.; Yanci, J. Análisis de las respuestas físicas y fisiológicas de árbitros y asistentes de fútbol durante partidos oficiales. RICYDE Rev. Int. Cienc. Deport. 2016, 45, 250-261. [CrossRef]

15. Barbero-Álvarez, J.C.; Boullosa, D.A.; Nakamura, F.Y.; Andrín, G.; Castagna, C. Physical and physiological demands of field and assistant soccer referees during America's cup. J. Strength Cond. Res. 2012, 26, 1383-1388. [CrossRef] [PubMed]

16. Castillo, D.; Yanci, J.; Cámara, J. Impact of official matches on soccer referees' power performance. J. Hum. Kinet. 2018, 61, 131-140. [CrossRef] [PubMed]

17. Castagna, C.; Abt, G.; D'Ottavio, S. Physiological aspects of soccer refereeing performance and training. Sport. Med. 2007, 37, 625-646. [CrossRef]

18. Krustrup, P.; Bangsbo, J. Physiological demands of top-class soccer refereeing in relation to physical capacity: Effect of Intense Intermittent exercise training. J. Sports Sci. 2001, 19, 881-891. [CrossRef]

19. Tessitore, A.; Cortis, C.; Meeusen, R.; Capranica, L. Power performance of soccer referees before, during and after official matches. J. Strength Cond. Res. 2007, 21, 1183-1187.

20. Helsen, W.; Bultynck, J.B. Physical and perceptual-cognitive demands of top-class refereeing in association football. J. Sports Sci. 2004, 22, 179-189. [CrossRef]

21. Castillo, D.; Camara, J.; Yanci, J. Influencia del criterio de determinación de la frecuencia cardiaca máxima sobre la cuantificación de la carga interna en el arbitraje. Arch. Med. Deport. 2018, 35, 228-233.

22. Di Salvo, V.; Carmont, M.R.; Maffulli, N. Football officials activities during matches: A comparison of activity of referees and linesmen in european, premiership and championship matches. Muscles Ligaments Tendons J. 2011, 1, 106-111. [PubMed]

23. Barbero-Álvarez, J.C.; Boullosa, D.A.; Nakamura, F.Y.; Andrín, G.; Weston, M. Repeated Acceleration Ability (RAA): A new concept with reference to top-level field and assistant soccer referees. Asian J. Sports Med. 2014, 5, 63-66. [CrossRef] [PubMed]

24. Catterall, C.; Reilly, T.; Atkinson, G.; Coldwells, A. Analysis of the work rates and heart rates of association football referees. Br. J. Sports Med. 1993, 27, 193-196. [CrossRef] 
25. Mallo, J.; Navarro, E.; Garcia Aranda, J.M.; Helsen, W. Physical demands of top-class soccer assistant refereeing during highstandard matches. Int. J. Sports Med. 2009, 30, 331-336. [CrossRef]

26. Weston, M.; Brewer, J. A study of the physiological demands of soccer refereeing. J. Sports Sci. 2002, $20,59-60$.

27. Krustrup, P.; Mohr, M.; Bangsbo, J. Activity profile and physiological demands of top-class soccer assistant refereeing in relation to training status. J. Sports Sci. 2002, 20, 861-871. [CrossRef]

28. Weston, M.; Drust, B.; Gregson, W. Intensities of exercise during match-play in FA premier league referees and players. J. Sports Sci. 2011, 29, 527-532. [CrossRef]

29. Navalta, J.W.; Montes, J.; Bodell, N.G.; Aguilar, C.D.; Radzak, K.; Manning, J.W.; de Beliso, M. Reliability of trail walking and running tasks using the stryd power meter. Int. J. Sports Med. 2019, 40, 498-502. [CrossRef]

30. Cerezuela-Espejo, V.; Hernández-Belmonte, A.; Courel-Ibáñez, J.; Conesa-Ros, E.; Mora-Rodríguez, R.; Pallarés, J.G. Are we ready to measure running power? Repeatability and concurrent validity of five commercial technologies. Eur. J. Sport Sci. 2020, 21, 341-350. [CrossRef]

31. Edwards, S. The Heart Rate Monitor Book; Polar Electro Oy: New York, NY, USA, 1993.

32. Cohen, J. Statistical Power Analysis for the Behavioral Sciences; Lawrence Erlbaum Associates, Ed.; Academic Press: Cambridge, MA, USA, 1998; ISBN 0805802835.

33. Costa, E.C.; Vieira, C.M.A.; Moreira, A.; Ugrinowitsch, C.; Castagna, C.; Aoki, M.S. Monitoring external and internal loads of brazilian soccer referees during official matches. J. Sport. Sci. Med. 2013, 12, 559-564.

34. Weston, M.; Gregson, W.; Castagna, C.; Breivik, S.; Impellizzeri, F.M.; Lovell, R.J. Changes in a top-level soccer referee's training, match activities, and physiology over an 8-year period: A case study. Int. J. Sport Psychol. Perform. 2011, 6, 281-286. [CrossRef] [PubMed]

35. Rampinini, E.; Impellizzeri, F.M.; Castagna, C.; Coutts, A.J.; Wisløff, U. Technical performance during soccer matches of the italian serie a league: Effect of fatigue and competitive level. J. Sci. Med. Sport 2009, 12, 227-233. [CrossRef] [PubMed]

36. Rampinini, E.; Impellizzeri, F.M.; Castagna, C.; Azzalin, A.; Bravo, D.F.; Wisløff, U. Effect of match-related fatigue on short-passing ability in young soccer players. Med. Sci. Sport Exerc. 2008, 40, 934-942. [CrossRef] [PubMed]

37. Castillo, D.; Raya, J.; Usabiaga, O.; Cámara, J.; Castellano, J.; Yanci, J. Analysis of the success in soccer match officials' decisions during an international tournament according to contextual factors. Rev. Int. Cienc. Deporte 2019, 15, 225-234. [CrossRef]

38. Reilly, T.; Bowen, T. Exertional costs of changes in directional modes of running. Percept. Mot. Skills 1984, 58, 149-150. [CrossRef] 